\title{
Arthropoda yang Berasosiasi dengan Tanaman Refugia pada Pertanaman Padi di Desa Besur, Kabupaten Lamongan, Jawa Timur
}

\section{(Arthropods Associating with Refugia Plant on Paddy Field in Besur Village, Lamongan District, East Java)}

\author{
Fathan Hadyan Rizki ${ }^{\star}$, Nina Maryana, Hermanu Triwidodo
}

(Diterima Mei 2020/Disetujui September 2020)

\begin{abstract}
ABSTRAK
Petani padi di Desa Besur menanam empat jenis tanaman refugia di sekitar pertanaman padi untuk meningkatkan pengendalian hayati sebagai bagian dari Program Manajemen Tanaman Sehat. Jenis-jenis tanaman refugia tersebut ialah Cosmos sulphureus, Helianthus annuus, Zinnia elegans, dan Sesamum indicum. Tujuan penelitian ini adalah untuk mempelajari Arthropoda yang berasosiasi dengan tanaman refugia tersebut. Penelitian ini telah dilakukan pada Bulan Desember 2017-Maret 2018 di Desa Besur, Kabupaten Lamongan, Provinsi Jawa Timur. Pengambilan sampel dilakukan pada masing-masing jenis tanaman refugia dengan metode branches beating, sweep net, pitfall trap, dan pengamatan langsung pada periode vegetatif, generatif, dan pascapanen tanaman padi. Hasil penelitian menunjukkan bahwa kebanyakan Arthropoda yang berasosiasi dengan tanaman refugia termasuk ordo Diptera, Hymenoptera, dan Araneae. Kelompok detritivor paling melimpah di semua periode. Analisis keanekaragaman serta kesamaan semua jenis refugia menunjukkan nilai sedang hingga tinggi dengan kesamaan tinggi satu sama lain.
\end{abstract}

Kata kunci: bunga, manajemen tanaman sehat, pengendalian hama terpadu, pertanaman padi, serangga bermanfaat

\section{ABSTRACT}

Rice farmers in Besur Village planted four species of refugia plants around rice plants to enhance biological control as a part of Healthy Plant Management Program. These refugia plants were flowering plants i.e., Cosmos sulphureus, Helianthus annuus, Zinnia elegans, and Sesamum indicum. The objective of this research was to observe the Arthropods associating with these refugia plants. This research was conducted in December 2017 to March 2018 at Besur Village, Lamongan District, East Java Province. Samples were obtained from each refugia species by branches beating, sweep net, pitfall trap, and direct observation method in the vegetative, generative, and postharvest periods paddy plant. The results showed that Arthropods associated with refugia plants are mostly belong to the order of Diptera, Hymenoptera, and Araneae. Detritivore group was the most abundant in all periods. Analysis of the diversity and similarity of all refugia species showed moderate to high values with high similarities each other.

Keywords: beneficial insect, flower, healthy plant management, integrated pest management, paddy field

\section{PENDAHULUAN}

Refugia adalah tempat yang disediakan untuk memberikan perlindungan pada tanaman dari gangguan ekologis di sekitarnya (FAO 2001). Dalam bidang perlindungan tanaman, penggunaan istilah refugia mengarah pada vegetasi khusus yang ditanam maupun tumbuh alami untuk mendukung upaya pengelolaan organisme pengganggu tanaman (OPT). Upaya tersebut dikenal sebagai manipulasi habitat yang menyokong pengendalian hayati konservasi karena mampu menghadirkan berbagai Arthropoda bermanfaat yang dapat menekan pupulasi OPT (Pfiffner \& Wyss 2004).

Tanaman yang digunakan sebagai tanaman refugia umumnya merupakan tanaman berbunga yang mampu

Departemen Proteksi Tanaman, Fakultas Pertanian, Institut Pertanian Bogor, Kampus IPB Darmaga, Bogor 16680

*Penulis Korespondensi: Email: fathan.hadriz@gmail.com memikat berbagai organisme bermanfaat (Kurniawati \& Martono 2015). Berkaitan dengan hal itu, Wahyuni et al. (2013) melaporkan bahwa tanaman refugia di pertanaman padi dikunjungi berbagai famili Arthropoda yang memiliki peran ekologis berbeda-beda. Menurut Lu et al. (2014), efektivitas berbagai tanaman refugia di suatu ekosistem pertanaman dalam mendukung pengendalian hayati akan bergantung pada pemilihan jenis tanaman yang digunakan. Oleh sebab itu, pemilihan jenis tanaman refugia perlu diperhatikan.

Salah satu wilayah di Indonesia yang telah memanfaatkan tanaman refugia adalah Desa Besur, Kecamatan Sekaran, Kabupaten Lamongan, Jawa Timur. Petani di desa tersebut menanam berbagai jenis tanaman berbunga di sekitar pertanaman padi. Jenis tanaman yang dimanfaatkan antara lain kenikir, Cosmos sulphureus Cav.; bunga matahari, Helianthus annuus L.; bunga kertas, Zinnia elegans Jacq. (Asteraceae); dan wijen, Sesamum indicum L. (Pedaliaceae). Penanaman refugia tersebut meru- 
pakan bagian dari program Manajemen Tanam Sehat (MTS). MTS adalah salah satu model penerapan Pengendalian Hama Terpadu (PHT) yang mengedepankan tiga aspek manjemen, yaitu manajemen tanah, tanaman, dan OPT (Mudjiono 2018, komunikasi pribadi). Dalam hal manajemen OPT, program tersebut menekankan pada penanaman refugia dan substitusi pestisida sintetik dengan pestisida berbahan agens hayati. Dengan program MTS tersebut, Desa Besur berhasil mencapai panen raya seluas 100 ha dengan rata-rata hasil panen 10 ton/ha (Timesindonesia 2017).

Keberhasilan tersebut merupakan hal yang baru, khususnya dalam bidang perlindungan tanaman. Data ekologi, khususnya struktur komunitas Arthropoda pada beberapa jenis tanaman refugia tersebut penting untuk diteliti. Tujuan penelitian ini adalah mempelajari Arthropoda yang berasosiasi dengan tanaman refugia di lokasi tersebut. Data yang ditemukan dapat menjadi acuan untuk pemanfaatan tanaman refugia lebih lanjut.

\section{METODE PENELITIAN}

\section{Waktu dan Tempat}

Pengambilan sampel Arthropoda dilaksanakan di pertanaman padi Desa Besur, Kecamatan Sekaran, Kabupaten Lamongan, Jawa Timur. Pengambilan sampel tersebut dilakukan dalam tiga periode yang mewakili fase pertumbuhan tanaman padi, yaitu fase vegetatif (5 minggu setelah tanam), generatif (10 minggu setelah tanam), dan pascapanen (2 minggu setelah panen) yang bertepatan dengan bulan Desember 2017-Maret 2018. Kegiatan identifikasi Arthropoda dilaksanakan pada bulan Januari-Mei 2018 di Laboratorium Biosistematika Serangga, Departemen Proteksi Tanaman, Fakultas Pertanian, Institut Pertanian Bogor.

\section{Penentuan Hamparan Contoh}

Hamparan ditentukan secara purposif dengan memerhatikan keberadaan empat jenis tanaman refugia di sekitar pertanaman padi. Jenis tanaman

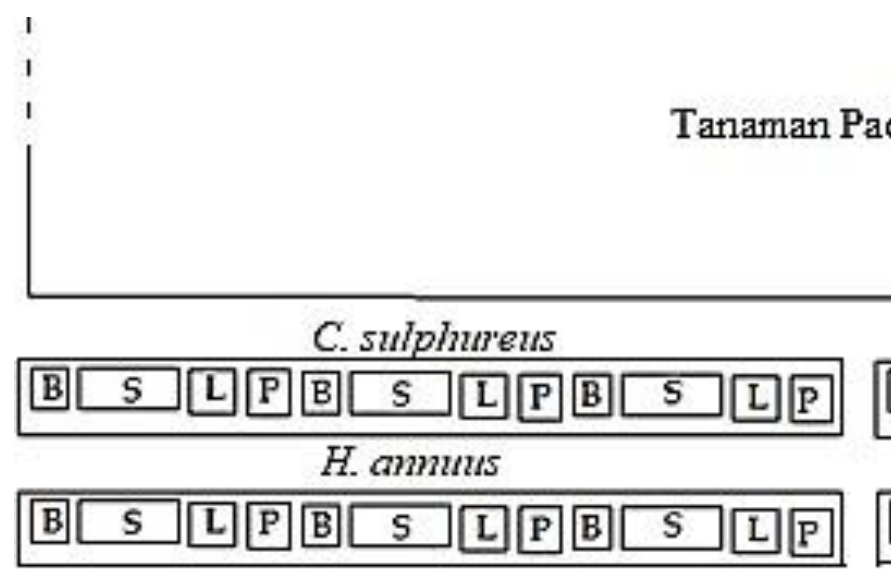

refugia tersebut adalah kenikir, bunga matahari, bunga kertas, dan wijen. Pengamatan dilakukan pada tiga hamparan pertanaman padi sebagai ulangan. Luas hamparan berkisar antara 8-14 ha. Verietas padi yang ditanam umumnya adalah Ciherang. Tanaman refugia ditanam dalam formasi barisan di pematang sawah, namun ada juga yang ditanam secara menyebar pada titik-titik tertentu. Tata letak titik contoh berbeda pada setiap hamparan, namun kebanyakan dalam formasi barisan (Gambar 1). Panjang barisan refugia di setiap pematang dapat mencapai $200 \mathrm{~m}$. Panjang barisan setiap jenis refugia bervariasi, dari $10-50 \mathrm{~m}$ atau lebih. Berdasarkan keterangan petani, refugia tidak selalu ditanam secara serentak sehingga dalam penelitian ini umur tanaman refugia bervariasi, namun umumnya telah berbunga.

\section{Pengambilan Sampel}

Pengambilan sampel Arthropoda pada semua jenis refugia dilakukan melalui empat cara, yaitu pitfall trap, sweep net, branches beating, dan pengamatan langsung. Pitfall trap dipasang pada pukul 16.00 WIB dan dibiarkan selama $2 \times 24$ jam. Cara lainnya dilakukan pada pagi hari pukul 07.00-11.00 WIB.

Pengambilan contoh dengan Pitfall trap dilakukan secara pasif dengan membuat lubang perangkap di permukaan tanah. Pada lubang tersebut dibenamkan wadah penampung berupa wadah plastik dengan posisi bukaan wadah sejajar dengan permukaan tanah. Ukuran diameter bukaan wadah ialah $6 \mathrm{~cm}$ dengan tinggi $6,5 \mathrm{~cm}$. Wadah plastik tersebut diisi larutan formaldehida $4 \%$ sebanyak $40 \mathrm{~mL}$ untuk pengawetan sementara Arthropoda yang terperangkap. Untuk mengantisipasi masuknya air hujan ataupun gangguan lainnya, lubang perangkap diberi penutup berbahan seng yang berbentuk seperti atap. Lubang perangkap dibuat tepat di bawah satu tanaman refugia.

Pengambilan contoh dengan Sweep net dilakukan secara aktif menggunakan jaring serangga yang diayun di atas tanaman refugia. Jaring tersebut berbahan kain organdi dengan ukuran diameter bukaan jaring $0,4 \mathrm{~m}$ dan panjang tangkai $1,5 \mathrm{~m}$.

Gambar 1 Denah titik pengambilan sampel Arthropoda pada tanaman refugia di pertanaman padi, (B) branches beating, (S) sweep net, $(\mathrm{L})$ pengamatan langsung, dan $(\mathrm{P})$ pitfall trap. 
Pengayunan jaring dilakukan sambil melangkah ke depan hingga mencakup tiga tanaman dengan jarak sekitar 1,5 m. Jumlah ayunan pada setiap titik contoh adalah tiga kali ayunan ganda untuk setiap tanaman yang dilalui. Serupa dengan itu, Branches beating dilakukan menggunakan jaring serangga yang sama. Bedanya jaring tidak diayun, namun diletakkan di bawah tajuk tanaman yang ditepuk atau diguncang sehingga Arthropoda jatuh dan tertampung di dalam jaring. Pada teknik ini, tepukan tidak dilakukan sambil melangkah sehingga hanya mencakup satu tanaman dengan jumlah tepukan yang dibatasi sebanyak 20 kali secara merata di semua sisi tajuk tanaman.

Secara keseluruhan, jumlah tanaman refugia yang diamati untuk semua jenis refugia, teknik pengambilan, periode pengamatan, beserta ulangannya mencapai 648 tanaman. Arthropoda yang diperoleh tanaman refugia tersebut dipisahkan dari sampah serasah kemudian dimasukkan ke dalam botol plastik berukuran diameter $3 \mathrm{~cm}$ dengan tinggi $5 \mathrm{~cm}$. Botol tersebut berisi alkohol $70 \%$ sebanyak $10 \mathrm{~mL}$ sehingga diharapkan kondisi sampel tetap baik sampai proses identifikasi di laboratorium. Dalam penelitian ini, teknik pengamatan langsung dilakukan tanpa penangkapan Arthropoda.

\section{Pengamatan Khusus Selama 24 Jam}

Pengamatan khusus 24 jam dilakukan hanya pada tanaman wijen pada saat periode pascapanen. Pengamatan dilakukan dengan cara pengamatan langsung pada tiga tanaman sebagai ulangan dengan waktu pengamatan 8 menit setiap jam. Jumlah dan famili Arthropoda yang teramati dicatat.

\section{Identifikasi Arthropoda}

Arthropoda diidentifikasi berdasarkan karakter morfologi hingga tingkat family menggunakan mikroskop stereo OLYMPUS SZ51. Identifikasi dilakukan dengan berpedoman pada kunci identifikasi yang terdapat pada beberapa acuan, di antaranya menurut Levi et al. (1968) dan CSIRO (2000).

\section{Analisis Data}

Data Arthropoda dari setiap jenis refugia dikelompokkan berdasarkan taksa serta peran ekologisnya menjadi sebuah database dengan bantuan perangkat lunak Microsoft Office Excel 2010. Database tersebut kemudian digunakan untuk menghitung nilai indeks keanekaragaman Shannon-Wiener $\left(\mathrm{H}^{\prime}\right)$, kemerataan (E), dan kesamaan Sørensen (IS) berdasarkan Magurran (2004). Berikut adalah rumus yang digunakan dalam penghitungan nilai indeks tersebut.

Nilai $\mathrm{H}^{\prime}$ dihitung dengan rumus:

$H^{\prime}=-\Sigma P i \ln (P i)$,

Keterangan:

$\mathrm{H}^{\prime}=$ Indeks keanekaragaman

$P i=(n i / N)$

$n i=$ Jumlah individu famili ke-i,

$N=$ Jumlah individu semua familli.
Nilai $E$ dihitung dengan rumus:

$E=H^{\prime} / H \max =H^{\prime} / \ln (S)$

Keterangan:

$\mathrm{E}=$ Indeks kemerataan

$\mathrm{S}=$ Jumlah famili

$\mathrm{H}^{\prime}=$ Indeks keanekaragaman

Nilai IS dihitung dengan rumus:

IS $=2 a /(2 a+b+c)$

Keterangan:

IS = Indeks kesamaan

$a=$ Jumlah famili yang sama pada kedua komunitas

$b=$ Jumlah famili eksklusif komunitas pertama

$c=$ Jumlah famili eksklusif komunitas kedua

\section{HASIL DAN PEMBAHASAN}

\section{Komposisi dan Kelimpahan Arthropoda}

Arthropoda yang ditemukan dalam penelitian ini berjumlah 13.494 individu yang terdiri atas 4 subfilum, 6 kelas, dan 21 ordo (Tabel 1). Subfilum Hexapoda dan Chelicerata menjadi kelompok yang paling tinggi kelimpahannya. Kelompok tersebut pada umumnya merupakan komponen penting dalam ekosistem sawah, seperti serangga (Insecta) dan laba-laba (Arachnida). Subfilum Crustacea dan Myriapoda kelimpahannya kurang dari $1 \%$ sehingga tidak banyak dibahas dalam penelitian ini.

Arthropoda paling banyak ditemukan pada tanaman kenikir dan paling sedikit ditemukan pada tanaman wijen. Kondisi ini diduga berkaitan dengan faktor keberadaan dan kondisi tanaman. Pada lokasi pengamatan terlihat bahwa tanaman kenikir mudah untuk tumbuh secara alami melalui runtuhan benihnya di sekitar pematang sawah. Kondisi ini dapat memberikan keuntungan bagi berbagai Arthropoda karena menyediakan tempat singgah ataupun sumber makanan lebih awal.

Berdasarkan periode pengamatannya, Arthropoda paling banyak ditemukan pada periode vegetatif, sedangkan paling sedikit ditemukan pada periode generatif (Tabel 2). Kondisi ini sesuai dengan penelitian Witryianto et al. (2015) yang menunjukkan bahwa di pertanaman padi organik, kelimpahan Arthropoda pada periode vegetatif lebih tinggi daripada periode generatif maupun pascapanen. Meski demikian, penelitian tersebut hanya mengamati kondisi Arthropoda pada tanaman padi, bukan pada tanaman refugia atau tumbuhan liar di pematang sawah.

Refugia dari Famili Asteraceae tampaknya menarik bagi banyak Arthropoda di semua periode pengamatan. Dari Tabel 2 tersebut diketahui bahwa pada saat periode vegetatif dan generatif, Arthropoda paling banyak ditemukan pada bunga matahari. Di samping itu, pada saat periode pascapanen, Arthropoda paling banyak ditemukan pada tanaman kenikir. Suparni et al. (2017) menjelaskan bahwa tanaman Asteraceae di 
Tabel 1 Komposisi dan kelimpahan Arthropoda di lokasi penelitian (individu)

\begin{tabular}{|c|c|c|c|c|c|c|c|}
\hline \multirow{2}{*}{ Subfilum } & \multirow{2}{*}{ Kelas $(\Sigma$ ordo $)$} & \multicolumn{4}{|c|}{ Jenis refugia } & \multirow{2}{*}{ Total } & \multirow{2}{*}{$(\%)$} \\
\hline & & $\mathrm{Kn}$ & $\mathrm{Bm}$ & $\mathrm{Bk}$ & $\mathrm{Wj}$ & & \\
\hline Chelicerata & Arachnida (3) & 396 & 299 & 314 & 335 & 1344 & 9.96 \\
\hline Crustacea & Malacostraca (1) & 1 & 2 & 0 & 6 & 9 & 0.07 \\
\hline \multirow[t]{2}{*}{ Hexapoda } & Ellipura (1) & 834 & 1141 & 1091 & 546 & 3612 & 26.77 \\
\hline & Insecta (13) & 2720 & 2187 & 1810 & 1806 & 8523 & 63.16 \\
\hline \multirow[t]{3}{*}{ Myriapoda } & Chilopoda (1) & 1 & 0 & 1 & 0 & 2 & 0.01 \\
\hline & Diplopoda (2) & 1 & 0 & 3 & 0 & 4 & 0.03 \\
\hline & Total & 3953 & 3629 & 3219 & 2693 & 13494 & 100.00 \\
\hline
\end{tabular}

Keterangan: $\mathrm{Kn}=$ Kenikir, $\mathrm{Bm}=$ Bunga matahari, $\mathrm{Bk}=$ Bunga kertas, dan $\mathrm{Wj}=\mathrm{Wijen}$.

Tabel 2 Kelimpahan Arthropoda pada setiap ordo dalam tiga periode pengamatan (individu)

\begin{tabular}{|c|c|c|c|c|c|c|}
\hline \multirow{2}{*}{ Periode } & \multirow{2}{*}{ Ordo } & \multicolumn{4}{|c|}{ Jenis refugia } & \multirow{2}{*}{ Total } \\
\hline & & $\mathrm{Kn}$ & $\mathrm{Bm}$ & $\mathrm{Bk}$ & $\mathrm{Wj}$ & \\
\hline \multirow[t]{12}{*}{ Vegetatif } & Acari & 5 & 3 & 6 & $7^{*}$ & 21 \\
\hline & Araneae & 96 & 76 & 83 & $122^{*}$ & 377 \\
\hline & Coleoptera & 63 & 67 & 78 & $91^{*}$ & 299 \\
\hline & Collembola & 717 & $1072^{*}$ & 964 & 454 & 3207 \\
\hline & Diptera & 348 & 261 & 184 & $465^{*}$ & 1258 \\
\hline & Hemiptera & 41 & 70 & 64 & $72^{*}$ & 247 \\
\hline & Hymenoptera & $192^{*}$ & 164 & 94 & 142 & 592 \\
\hline & Lepidoptera & $11^{*}$ & 9 & 7 & 8 & 35 \\
\hline & Odonata & 6 & 5 & 5 & $11^{*}$ & 27 \\
\hline & Orthoptera & 5 & 0 & $10^{*}$ & 9 & 24 \\
\hline & Lainnya & 14 & 8 & 43 & 30 & 63 \\
\hline & Total & 1498 & $1735^{*}$ & 1517 & 1400 & 6150 \\
\hline \multirow[t]{12}{*}{ Generatif } & Acari & 8 & 4 & 7 & $12^{*}$ & 31 \\
\hline & Araneae & $158^{*}$ & 115 & 90 & 138 & 501 \\
\hline & Coleoptera & 63 & $162^{*}$ & 64 & 50 & 339 \\
\hline & Collembola & 84 & 64 & 80 & $90^{*}$ & 318 \\
\hline & Diptera & $234^{*}$ & 174 & 146 & 171 & 725 \\
\hline & Hemiptera & 75 & $197^{*}$ & 73 & 56 & 401 \\
\hline & Hymenoptera & 130 & 96 & 158 & $216^{*}$ & 600 \\
\hline & Lepidoptera & $24^{*}$ & 11 & 11 & 16 & 62 \\
\hline & Orthoptera & 3 & 4 & $5^{*}$ & 3 & 15 \\
\hline & Thysanoptera & 44 & 17 & $53^{*}$ & 25 & 139 \\
\hline & Lainnya & 9 & 6 & 17 & 13 & 45 \\
\hline & Total & 832 & $850^{*}$ & 704 & 790 & 3176 \\
\hline \multirow[t]{12}{*}{ Pascapanen } & Araneae & $126^{*}$ & 101 & 123 & 54 & 404 \\
\hline & Coleoptera & 40 & $68^{*}$ & 44 & 8 & 160 \\
\hline & Collembola & 33 & 5 & $47^{*}$ & 2 & 87 \\
\hline & Diptera & $1073^{*}$ & 616 & 531 & 279 & 2499 \\
\hline & Hemiptera & $44^{*}$ & 37 & 36 & 36 & 153 \\
\hline & Hymenoptera & $259^{*}$ & 185 & 150 & 119 & 713 \\
\hline & Lepidoptera & 6 & $19^{*}$ & 9 & 1 & 35 \\
\hline & Odonata & $17^{*}$ & 7 & 9 & 0 & 33 \\
\hline & Orthoptera & 8 & 2 & $16^{*}$ & 3 & 29 \\
\hline & Thysanoptera & 13 & 0 & $26^{*}$ & 0 & 39 \\
\hline & Lainnya & 4 & 4 & 7 & 1 & 16 \\
\hline & Total & $1623^{*}$ & 1044 & 998 & 503 & 4168 \\
\hline
\end{tabular}

Keterangan: "Kelimpahan tertinggi di antara jenis refugia. $\mathrm{Kn}=$ Kenikir, $\mathrm{Bm}=$ Bunga matahari, Bk $=\mathrm{Bunga}$ kertas, dan $\mathrm{Wj}=$ Wijen.

pertanaman padi dapat meningkatkan kehadiran Arthropoda dengan peran yang beraneka ragam.

Secara umum, kelompok Arthropoda yang melimpah di setiap periode cenderung sama, termasuk di antaranya Ordo Diptera, Hymenoptera, dan Araneae. Beberapa penelitian menunjukkan bahwa ordo tersebut sering ditemukan pada tanaman refugia (Suparni et al. 2017; Daniati et al. 2018). Sebaran Arthropoda tersebut pada tanaman refugia cenderung acak. Misalnya, Diptera pada saat periode vegetatif paling melimpah pada tanaman wijen, namun pada periode berikutnya Diptera paling melimpah pada tanaman kenikir. Berbeda dari keadaan itu, Hymenoptera pada saat periode vegetatif dan pascapanen melimpah pada kenikir, sedangkan pada saat periode generatif paling melimpah pada wijen.

Selanjutnya diketahui bahwa Arthropoda yang ditemukan dalam penelitian ini terdiri atas 147 famili. Dari semua famili tersebut, dua puluh famili yang paling melimpah untuk setiap jenis refugia ditampilkan pada Gambar 2. Ordo yang belum teridentifikasi hingga 


$\begin{array}{r:cc}\text { Anthicidae (PR) } & 30 & \text { Kenikir } \\ \text { Aphididae (HE) } & 32 \\ \text { Apidae (PO) } & 27 \\ \text { Araneidae (PR) } & 58 \\ \text { Ceratopogonidae (PR) } & 212 \\ \text { Chironomidae (DE) } & \\ \text { Chloropidae (HE) } & 32 \\ \text { Chrysomelidae (HE) } & 29 \\ \text { Cicadellidae (HE) } & 30 \\ \text { Coccinellidae (PR) } & 63 \\ \text { Ephydridae (HE) } & 30 \\ \text { Formicidae (PR) } & \\ \text { Linyphiidae (PR) } & 30 \\ \text { Oxyopidae (PR) } & 56 \\ \text { Pseudococcidae (HE) } & 37 \\ \text { Salticidae (PR) } & 31 \\ \text { Scelionidae (PA) } & 21 \\ \text { Tetragnathidae (PR) } & 45 \\ \text { Theridiidae (PR) } & 102 \\ \text { Triozidae (HE) } & 39\end{array}$

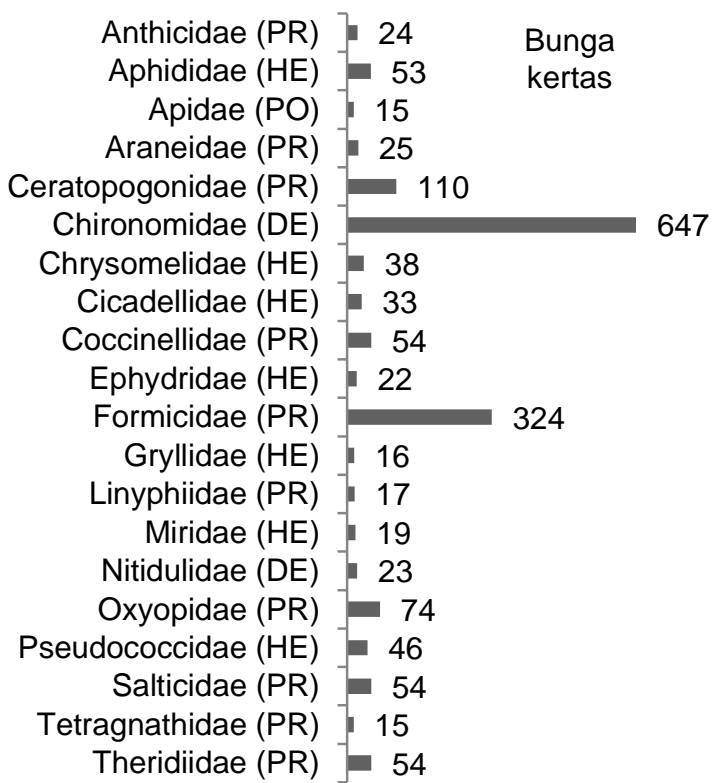

\begin{tabular}{r|cl} 
Anthicidae (PR) & 13 & Bunga \\
Anthribidae (DE) & 16 & matahari \\
Aphididae (HE) & 49 & \\
Araneidae (PR) & 33 & \\
Ceratopogonidae (PR) & 121 \\
Chironomidae (DE) & & \\
Chloropidae (HE) & 27 & \\
Chrysomelidae (HE) & 23 & \\
Cicadellidae (HE) & 92 \\
Coccinellidae (PR) & 79 \\
Curculionidae (HE) & 17 \\
Ephydridae (HE) & 16 \\
Formicidae (PR) & \\
Nitidulidae (DE) & 134 \\
Oxyopidae (PR) & 38 \\
Pseudococcidae (HE) & 140 \\
Salticidae (PR) & 30 \\
Tetragnathidae (PR) & 65 \\
Theridiidae (PR) & 63 \\
Thomisidae (PR) & 14
\end{tabular}

\begin{tabular}{r|cc} 
Anthicidae (PR) & 21 & Wijen \\
Aphididae (HE) & 19 & \\
Apidae (PO) & 19 & \\
Calliphoridae (DE) & 21 & 257 \\
Ceratopogonidae (PR) & & 487 \\
Chironomidae (DE) & \\
Chloropidae (HE) & 27 \\
Chrysomelidae (HE) & 23 \\
Cicadellidae (HE) & 25 \\
Coccinellidae (PR) & 66 \\
Ephydridae (HE) & 31 \\
Formicidae (PR) & 385 \\
Linyphiidae (PR) & 18 \\
Miridae (HE) & 48 \\
Oxyopidae (PR) & 62 \\
Pentatomidae (HE) & 27 \\
Pseudococcidae (HE) & 26 \\
Salticidae (PR) & 38 \\
Tetragnathidae (PR) & 25 \\
Theridiidae (PR) & \\
\hline
\end{tabular}

Gambar 2 Famili terbanyak beserta peranannya pada setiap jenis refugia (individu). $\mathrm{DE}=\mathrm{Detritivor}, \mathrm{HE}=\mathrm{Herbivor}, \mathrm{PA}=$ Parasitoid, $\mathrm{PO}=$ Polinator, dan $\mathrm{PR}=$ Predator.

tingkat famili seperti Collembola, Thysanoptera, dan Acari tidak termasuk dalam data tersebut.

Familli Chironomidae, Ceratopogonidae (Ordo Diptera), dan Formicidae (Ordo Hymenoptera) ditemukan hampir selalu paling melimpah pada semua jenis refugia. Selain famili tersebut, ditemukan juga famili lainnya yang kelimpahannya melebihi 100 individu, namun hanya pada tanaman refugia tertentu. Pseudococcidae (Ordo Hemiptera) dan Nitidulidae (Ordo Coleoptera) kelimpahannya tinggi pada bunga matahari, sedangkan Theridiidae (Ordo Araneae) kelimpahannya tinggi pada kenikir dan wijen.

Chironomidae dan Nitidulidae berperan sebagai detritivor. Detritivor memfasilitasi proses dekomposisi dengan cara memecah bahan organik yang berukuran besar menjadi partikel yang lebih kecil (Leksono 2017). Larva Chironomidae hidup di perairan dan memakan detritus maupun organisme lainnya yang berukuran mikro. Pada habitat yang hangat, Chironomidae dapat bersifat multivoltine atau memiliki banyak generasi keturunan dalam setahun sehingga kelimpahannya sangat tinggi (Oliver 1981). Starzomski et al. (2010) menunjukkan bahwa Chironomidae menjadi mangsa yang penting sehingga dapat menghadirkan beberapa Arthropoda predator. Di samping itu, beberapa spesies dari famili Nitidulidae telah diketahui berasosisasi dengan beberapa jenis tanaman berbunga, seperti Aster sp., Antennaria neglecta Greene., dan Eupatorium rugosum Houtt. (Asteraceae) (Price \& Young 2006). 
Tiga Famili serangga, yaitu Ceratopogonidae, Theridiidae, dan Formicidae berperan sebagai predator. Famili Ceratopogonidae diketahui sering mendatangi bunga untuk mendapatkan nutrisi tambahan, bahkan jenis tertentu menjadi polinator yang sangat baik di perkebunan kakao (O'Doherty \& Zoll 2012). Di samping itu, kelompok laba-laba Therididiae termasuk predator yang penting pada pertanaman padi. Changming (1989) menunjukkan bahwa Therididae berpotensi untuk menekan populasi salah satu hama padi, yaitu wereng batang cokelat (Nilaparvata lugens Stål.). Sementara itu, semut (Ordo Formicidae) merupakan predator yang mudah ditemui pada banyak tanaman. Way et al. (1998) melaporkan bahwa beberapa jenis semut dapat memangsa hama padi tertentu dari ordo Hemiptera, Lepidoptera, bahkan hama non-Arthropoda, seperti keong emas (Pomacea canaliculata Lamarck.).

Salah satu Arthropoda yang berperan sebagai herbivora pada penelitian ini adalah Pseudococcidae. Kelimpahan arthropoda ini cukup tinggi, terutama pada bunga matahari. Kondisi ini sesuai dengan hasil penelitian Abbas et al. (2010) yang menunjukkan bahwa bunga matahari merupakan salah satu tanaman inang bagi Pseudococcidae. Herbivor lainnya yang cukup sering ditemukan pada bunga matahari ialah Famili Cicadellidae. Beberapa jenis famili tersebut bahkan dapat mengancam pertanaman padi karena dapat membawa virus tungro (Cook \& Perfect 1989). Oleh sebab itu, keberadaan predator bagi famili ini dibutuhkan, misalnya Coccinellidae (Ordo Coleoptera). Famili Coccinellidae golongan predator dapat menekan populasi salah satu jenis wereng Nephotettix sp. (Cicadellidae) (Rattanapun 2012).

Pada penelitian ini, kelimpahan polinator dan parasitoid relatif rendah. Salah satu polinator yang sering ditemukan adalah Apidae (Ordo Hymenoptera). Banyak jenis famili tersebut merupakan penerbang cepat sehingga tidak tercatat dalam proses pengambilan sampel, kecuali pengamatan langsung.
Meski demikian, Arthropoda lain secara tidak langsung dapat berperan juga sebagai polinator. Di samping itu, satu-satunya parasitoid yang kelimpahannya cukup tinggi adalah Scelionidae, terutama pada tanaman kenikir. Scelionidae berpotensi menekan populasi beberapa jenis hama, salah satunya Nezara viridula Linnaeus. (Famili Pentatomidae) (Jones 1988).

\section{Distribusi Temporal Arthropoda}

Secara keseluruhan, Arthropoda yang berperan sebagai detritivor berjumlah 38 famili, herbivor sebanyak 44 famili, polinator sebanyak 4 famili, parasitoid sebanyak 21 famili, dan predator sebanyak 40 famili. Berdasarkan periode pengamatannya, kecenderungan yang terjadi pada setiap periode hampir sama. Kelompok detritivor selalu paling melimpah, kemudian diikuti oleh predator dan herbivor (Gambar 3). Kelompok polinator dan parasitoid kelimpahannya cenderung rendah dalam kisaran 1$2 \%$. Kelimpahan kelompok herbivor dan predator pada periode generatif lebih tinggi dibandingkan dengan periode lainnya. Peran Arthropoda tersebut saling melengkapi satu sama lain sehingga keberadaan semua kelompok memegang peran sangat penting bagi keberlanjutan pertanaman padi di Desa Besur.

Menurut Pfiffner \& Wyss (2004), manfaat tanaman berbunga bagi agroekosistem dapat melalui dua cara. Pertama, tanaman berbunga menyediakan sumber makanan bagi Arthropoda, kedua, tanaman berbunga menjadi alternatif habitat ketika melalui masa overwintering. Pada kasus pemanfaatan refugia di Desa Besur, cara pertama berlaku pada saat periode vegetatif maupun generatif padi, sedangkan cara kedua berlaku pada saat periode pascapanen ataupun masa bera. Dalam hal ini, overwintering dianggap serupa dengan kondisi periode pascapanen, yang pada waktu tersebut Arthropoda memerlukan tanaman lain sebagai habitat untuk menggantikan tanaman padi sementara waktu.
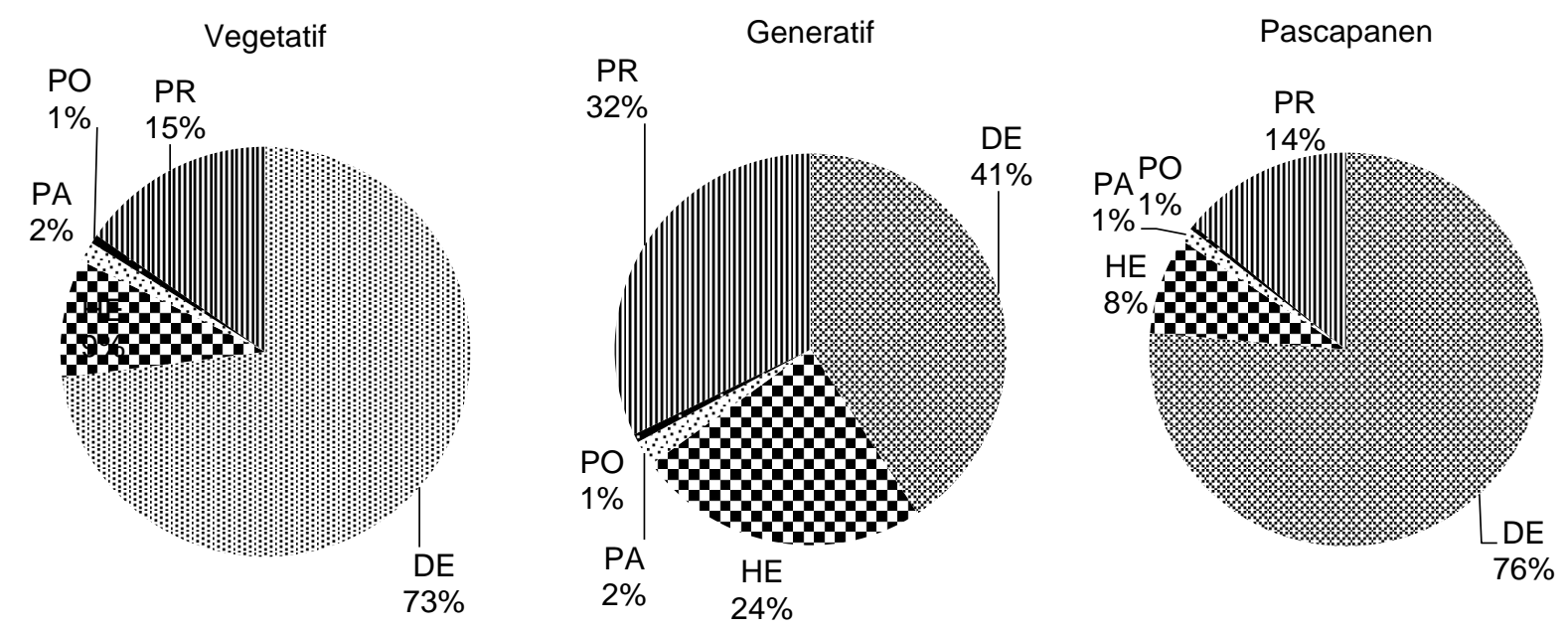

Gambar 3 Distribusi peran Arthropoda pada setiap periode pengamatan. DE = Detritivor, HE = Herbivor, PA = Parasitoid, $\mathrm{PO}=$ Polinator, dan PR = Predator . 
Hasil pengamatan selama 24 jam pada tanaman wijen pada saat periode pascapanen menunjukkan bahwa refugia banyak didatangi Arthropoda predator sejak awal hingga akhir pengamatan (Gambar 4). Kelimpahan predator cenderung mengalami kenaikan perlahan dari pukul $06.00 \mathrm{WIB}$ hingga pukul $18.00 \mathrm{WIB}$. Setelah itu, kelimpahannya meningkat drastis sehingga mencapai puncaknya pada pukul 23.00 WIB. Kelimpahan Arthropoda lainnya cenderung rendah dan statis selama pengamatan. Kondisi tersebut menunjukkan bahwa terdapat perbedaan kencenderungan dalam hal komposisi dan kelimpahan Arthropoda pada siang hari dan malam hari. Penelitian Arthropoda nokturnal perlu dilakukan lebih lanjut, khususnya mengenai Arthropoda predator di semua refugia.

\section{Indeks Keanekaragaman Arthropoda Kesamaan antara Jenis Refugia}

Nilai indeks keanekaragaman famili Arthropoda pada tanaman refugia berkisar antara sedang hingga tinggi (Tabel 3). Bunga kertas dan wijen memiliki keanekaragaman tinggi, sedangkan kenikir dan bunga matahari memiliki keanekaragaman yang sedang. Hal ini berarti semua jenis refugia pada penelitian ini cukup memadai sebagai habitat bagi berbagai Arthropoda untuk menyediakan jasa ekosistem yang optimal. Balzan et al. (2016) menjelaskan bahwa tanaman berbunga dapat meningkatkan kelimpahan maupun keanekaragaman Arthropoda yang menyediakan jasa ekosistem untuk meningkatkan produktivitas tanaman utama. Nilai kemerataan famili $(E)$ pada semua jenis refugia hanya berkisar pada nilai 0,55-0,66. Artinya, komunitas Arthropoda yang terdapat pada semua refugia dalam keadaan labil atau didominasi oleh sebagian kecil famili tertentu.

Nilai Indeks Sørensen yang didapatkan berkisar antara 73,58-80,18\% (Tabel 4). Hasil tersebut menunjukkan bahwa komposisi Arthropoda yang terdapat pada semua refugia memiliki kesamaan yang tinggi. Artinya, refugia memiliki fungsi yang mirip satu sama lain dalam hal menyediakan berbagai kelompok Arthropoda di sekitar pertanaman padi. Kondisi tersebut dapat dijelaskan oleh hasil penelitian Torres \& Galetto (2002) yang menunjukkan bahwa tidak terdapat korelasi antara sifat-sifat bunga dengan keanekaragaman Arthropoda pengunjung bunga. Meskipun masing-masing tanaman refugia tersebut memiliki fungsi yang mirip, hal itu bukan berarti bahwa petani cukup menanam salah satu jenis tanaman refugia saja. Menurut Barloggio et al. (2018), jenis tanaman refugia sebaiknya dikombinasikan antara jenis tanaman yang memiliki daya tarik tinggi dengan tanaman yang memiliki nektar extra-floral. Dengan begitu, Arthropoda pengunjung akan memiliki kinerja

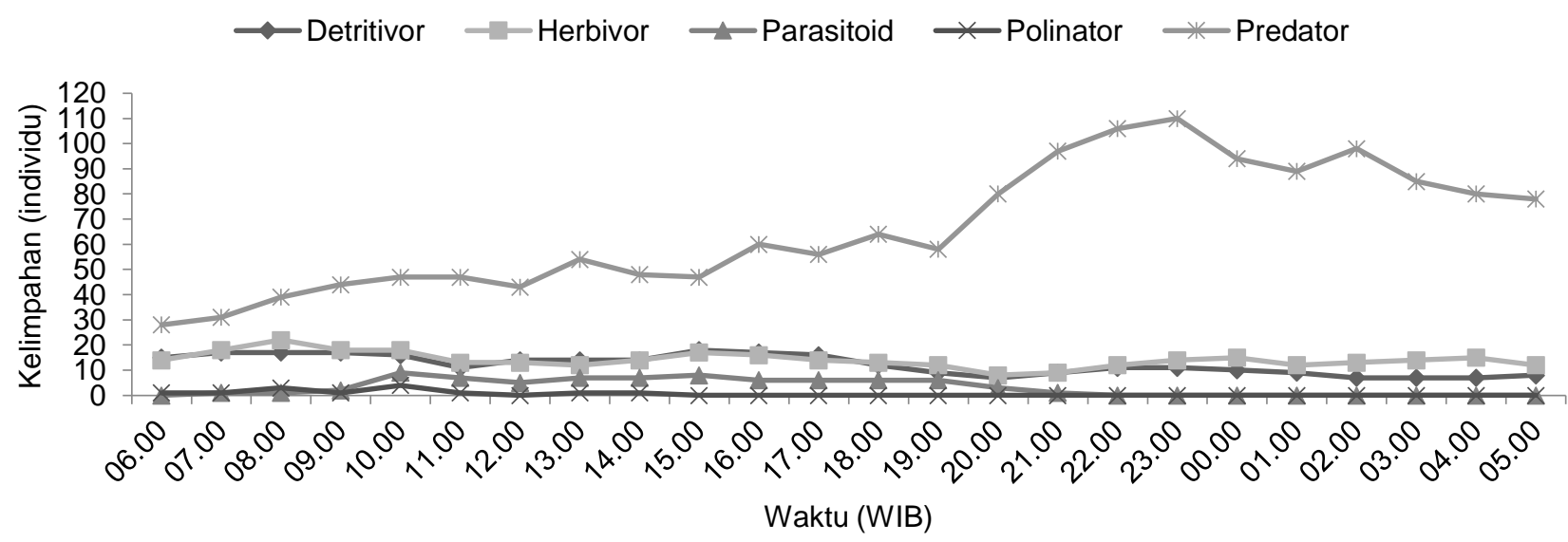

Gambar 4 Kelimpahan Arthropoda selama 24 Jam pada tanaman wijen

Tabel 3 Indeks keanekaragaman dan kemerataan famili

\begin{tabular}{lcccc}
\hline Jenis refugia & $\Sigma$ Ordo & $\Sigma$ Famili & $\mathrm{H}^{\prime}$ & $\mathrm{E}$ \\
\hline Kenikir & 19 & 103 & $2.53^{*}$ & 0.55 \\
Bunga matahari & 15 & 90 & $2.77^{\star}$ & 0.62 \\
Bunga kertas & 19 & 114 & $3.01^{\star *}$ & 0.64 \\
Wijen & 17 & 103 & $3.05^{\star *}$ & 0.66 \\
\hline
\end{tabular}

Keterangan: ${ }^{*}=$ Keanekaragaman sedang, ${ }^{* *}=$ Keanekeragaman tinggi, $\mathrm{H}=$ Indeks keanekaragaman, dan $\mathrm{E}=$ Indeks kemerataan.

Tabel 4 Indeks kesamaan antara jenis refugia (\%)

\begin{tabular}{lcccc}
\hline Jenis refugia & Kenikir & Bunga matahari & Bunga kertas & Wijen \\
\hline Kenikir & - & 73,58 & 80,18 & 73,79 \\
Bunga matahari & & - & 77,45 & 76,68 \\
Bunga kertas & & & - & 77,42 \\
Wijen & & & - \\
\hline
\end{tabular}


maupun daya tahan yang lebih baik. Selain itu, tanaman refugia yang bervariasi akan memberikan nilai estetik bagi pertanaman. Penelitian lebih lanjut, seperti inventarisasi Arthropoda pada tingkat jenis serta uji preferensi tanaman, diperlukan untuk melengkapi informasi penelitian ini.

\section{KESIMPULAN}

Arthropoda yang berasosiasi dengan tanaman refugia di pertanaman padi di Desa Besur sebagian besar termasuk ordo Diptera, Hymenoptera, dan Araneae. Kelompok detritivor memiliki kelimpahan yang tinggi di semua periode pengamatan. Analisis keanekaragaman dan kemiripan antara jenis refugia menunjukkan nilai keanekaragaman sedang hingga tinggi dengan kemiripan yang tinggi satu sama lain. Kondisi ini mendukung keberlanjutan pertanaman padi di Desa Besur.

\section{DAFTAR PUSTAKA}

Abbas G, Arif MJ, Ashfaq M, Aslam M, Saeed S. 2010. Host plants, distribution and overwintering of cotton mealybug (Phenacoccus solenopsis; Hemiptera: Pseudococcidae). International Journal of Agriculture and Biology. 12: 421-425.

Balzan MV, Bocci G, Moonen AC. 2016. Utilisation of plant functional diversity in wildflower strips for the delivery of multiple agroecosystem services. Entomologia Experimentalis et Applicata. 158(3): 304-319. https://doi.org/10.1111/eea.12403

Barloggio G, Tamm L, Nagel P, Luka H. 2018. Selective flowers to attract and enhance Telenomus laeviceps (Hymenoptera: Scelionidae): a released biocontrol agent Mamestra brassicae (Lepidoptera: Noctuidae). Bulletin of Entomological Research. 109(2): 160-168. https://doi.org/10.1017/S0007 485318000287

Cook AG, Perfect TJ. 1989. Population dynamics of three leafhopper vectors of rice tungro viruses, Nephotettix virescens (Distant), N. nigropictus (Stål) and Recilia dorsalis (Motschulsky) (Hemiptera: Cicadellidae), in farmers' fields in the Philippines. Bulletin of Entomological Resesearch. 79(3): 437451. https://doi.org/10.1017/S0007485300018447

[CSIRO] Commonwealth Scientific and Industrial Research Organization. 2000. The Insect of Australia: A Textbook for Students and Research Workers. 1st Edition dan 2nd Edition. Victoria (AU): Melbourne Univ Press.

Changming GFC. 1989. Laboratory and filed studies on the predation of Nilaparvata lugens (Homoptera: Delphacidae) by Theridion octomaculatum
(Araneae: Theridiidae). Chinese Journal of Biological Control. 5(2): 84-88.

Daniati C, Karindah S, Puspitarini, R. 2018. Three species of weeds enhance the population of predator and parasitoid of coffee berry borers. Biosaintifika. 10(1): 229-236. https://doi.org/ 10.15294/biosaintifika.v10i1.12076

[FAO] Food and Agriculture Organization. 2001. Glossary of biotechnology for food and agriculture a revised and augmented edition of the glossary of biotechnology and genetic enginering [internet]. [diakses 17 September 2017]. Tersedia pada: http://www.fao.org/docrep/004/Y2775E/Y277 5E00.HTM

Jones WA. 1988. World review of the parasitoids of the southern green stink bug, Nezara viridula L. (Heteroptera: Pentatomidae). Annals of the Entomolgical Society of America. 81(2): 262-273. https://doi.org/10.1093/aesa/81.2.262

Kurniawati N, Martono E. 2015. Peran tumbuhan berbunga sebagai media konservasi Arthropoda dan musuh alami. Jurnal Perlindungan Tanaman Indonesia. 19(2): 53-59. https://doi.org/ 10.22146/jpti.16615

Leksono AS. 2017. Ekologi Arthropoda. Malang (ID): UB Press.

Levi HW, Levi LR, Zim HS. 1968. A Guide to Spiders and Their Kin. New York (US). Golden Press.

Lu ZX, Zhu PY, Gurr GM, Zheng XS, Read DMY, Heong KL, Yang YJ, Xu HX. 2014. Mechanisms for flowering plants to benefit arthropod natural enemis of insect pests: Prospects for enhanced use in agriculture. Insect Science. 21(1): 1-12. https://doi.org/10.1111/1744-7917.12000

Magurran AE. 2004. Measuring Biological Diversity Assesment. Victoria (AU). Blackwell.

O'Doherty DCO, Zoll JJK. 2012. Forcipomyia hardyi (Diptera: Ceratopogonidae), a potential pollinator of cacao (Theobroma cacao) flowers in Hawaii. Di dalam: Proceeding of Hawaiian Entomological Society [internet]. [waktu dan tempat pertemuan tidak diketahui]. Hawaii (US): Hawaiian Entomological Society. HIm 79-81. [diunduh 2019 Nov 20]. Tersedia pada: https://scholar space.manoa.hawaii.edu /bitstream/10125/25464/ PHES-44_79-81.pdf

Oliver DR. 1981. Manual of Nearctic Diptera. Volume I. McAlpine JF, Peterson BV, Shewell GE, Teskey HJ, Vockerth JR, Wood DM, editor. Ottawa (CA): Research Branch Agriculture Canada.

Pfiffner L, Wyss E. 2004. Ecological Engineering for Pest Management: Advances in Habitat Manipulation for Arthorpods. Gurr GM, editor. Collingwood (AU): CSIRO. 
Price MB, Young DK. 2006. An annotated checklist of Wisconsin sap and short-winged flower beetles (Coleoptera: Nitidulidae, Kateretidae). Insecta Mundi. 20(1): 69-84.

Starzomski BM, Suen D, Srivastava DS, 2010. Predation and facilitation determine chironomid emergence in a bromeliad-insect food web. Ecological Entomology. 35(1): 53-60. https:// doi.org/10.1111/j.1365-2311.2009.01155.x

Rattanapun W. 2012. Biology and potentiality in biological control of Micraspis discolor (Fabricius) (Coleoptera: Coccinellidae). Communications in Agricultural and Applied Biological Science. 77(4): 541-548.

Suparni S, Putra NS, Suputa S. 2017. Population of herbivorous and carnivorous Arthropods in rice field ecosystem modified with vermicompost and flower plants. Jurnal Ilmu Pertanian. 2(2): 048-055. https://doi.org/10.22146/ipas.16983

Timesindonesia. 2017. Metode refugia sukses, Lamongan berniat perluasan lahan. [internet]. [diakses 10 September 2017]. Tersedia pada: https:// www.times indonesia.co.id/read/1424 28/20170214/141742/metode-refugia-sukseslamongan-berniat-perluasan-lahan/.

Torres C, Galetto L. 2002. Are nectar sugar composition and corolla tube length related to the diversity of insect that visit Asteraceae flowers? Plant Biology. 4(1): 360-366. https://doi.org/ 10.1055/s-2002-32326

Wahyuni R, Wijayanti R, Supriyadi. 2013. Peningkatan keragaman tumbuhan berbunga sebagai daya tarik predator hama padi. Journal of Agricultural Research. 2(5): 40-46.

Way MJ, Islam Z, Heong KL, Joshi RC. 1998. Ants in tropical irrigated rice: distribution and abundance, especially of Solenopsis geminata (Hymenoptera: Formicidae). Bulletin of Entomological Research. 88(1): 467-476. https://doi.org/10.1017/S000 7485300042218

Witriyanto R, Hadi M, Rahadian R. 2015. Keanekaragaman makroarthropoda tanah di lahan persawahan padi organik dan anorganik, Desa Bakalrejo Kecamatan Susukan Kabupaten Semarang. Bioma. 17(1): 21-26. https:// doi.org/10.14710/bioma.17.1.21-26 